\title{
Graves' Disease: Pathophysiological Aspects and Considerations about Using the Chemometric Analysis in the Study of the Disease
}

\author{
Pavlina M. Koseva ${ }^{1}, Z_{\text {dravko A. Kamenov }}^{2}$, Mariana M. Nikolova ${ }^{3}$, Pavlina A. Andreeva-Gateva ${ }^{4}$ \\ ${ }^{1}$ Department of Pharmaceutical Chemistry, Faculty of Pharmacy, Medical University of Varna, Varna, Bulgaria \\ ${ }^{2}$ Clinic of Endocrinology, Medical University of Sofia, Aleksandrovska State University Hospital, Sofia, Bulgaria \\ ${ }^{3}$ Department of Mental Health, Social Work and Integrative Medicine, Middlesex University, London, United Kingdom \\ ${ }^{4}$ Department of Pharmacology and Toxicology, Medical University of Sofia, Sofia, Bulgaria
}

Corresponding author: Pavlina A. Andreeva-Gateva, Department of Pharmacology and Toxicology, Medical University of Sofia, 2 Zdrave St., 1431 Sofia, Bulgaria; E-mail: pandreeva_gateva@outlook.com; Tel.: +359 889428105

Received: 3 Aug 2020 Accepted: 4 Sep 2020 Published: 31 Aug 2021

Citation: Koseva PM, Kamenov ZA, Nikolova MM, Andreeva-Gateva PA. Graves' disease: pathophysiological aspects and considerations about using the chemometric analysis in the study of the disease. Folia Med (Plovdiv) 2021;63(4):467-74. doi: 10.3897/folmed.63. e57193.

\begin{abstract}
Graves' disease is an immune system disorder that results in the overproduction of thyroid hormones (hyperthyroidism). Thyroid disorders are a societal problem of great public concern because of their high prevalence. This problem can affect the well-being and quality of life of patients. The predisposing factors leading to this disease are not yet fully established and are likely to be interconnected in a complex way.

Chemometric analysis allows for the detection of specific relationships between the medical parameter measurements obtained from the patients in an observation group, and the identification of patterns of similarity between these patients. It is not commonly used in clinical trials; however, it can provide reliable information which may help in creating more successful, individualised treatment strategies for established groups (patterns) of patients.

The aim of this review is to summarize the latest knowledge about the risk factors for Graves' disease and considerations about using the chemometric analysis in the study of the disease.
\end{abstract}

\section{Keywords}

autoimmunity, goiter, review, risk factors

\section{INTRODUCTION}

Diseases that have an economic and psychological effects on the quality of life of the population and are often the cause of disability and poor functioning in the implementation of everyday activities are defined as socially important diseases. ${ }^{1}$ Endocrine diseases, with the exception of diabetes mel- litus, are often not attributable to socially significant diseases because they do not have all of the above-mentioned characteristics. However, they can gradually deteriorate the quality of life of affected individuals and their families. Thyroid gland autoimmune disorders in general and Graves' disease in particular are not fatal but timely treatment is essential for controlling the condition and avoiding severe consequences. 
Graves' disease (GD) is named after Dr. Robert J. Graves who first described a case of it in 1835. The term Basedow's disease is more commonly used in continental Europe; in the UK and USA, it is largely known as Graves' disease.

Thyroid gland autoimmune disturbances are caused by the immune system attacking healthy tissues by creating antibodies, which provokes the thyroid to grow and produce more thyroid hormones than necessary for normal body functions. These antibodies are known as thyroidstimulating immunoglobulins (TSIs). The TSIs connect to thyroid cell receptors which serve as "docking stations" for the thyroid-stimulating hormone (TSH) and the TSHReceptor antibodies (TRAb) cause the thyroid to produce too much of the thyroid hormone, leading to the condition called hyperthyroidism. ${ }^{2}$

Graves' disease is suspected based on symptoms and findings during a physical examination, but to confirm the diagnosis, further blood or imaging tests should be carried out. These are used to conclusively diagnose GD and differentiate it from other autoimmune diseases that feature the presence of thyroid antibodies.

The objectives of this study were to review the pathophysiological aspects of Graves' disease and make some considerations about using the chemometric analysis in the study of the disease.

The Central Medical Library at 1 St Georgi Sofiyski Street, 1431 Sofia Center, Sofia, Bulgaria was searched from inception to June 2019 with the following key words: Graves' disease, hyperthyroidism, overactive thyroid, risk factors. This review includes human studies published in the past 10 years.

\section{FINDINGS}

Numerous causes have been found to increase the risk of disease. Although a clear causal mechanism has not been established, the onset of Graves' disease seems to be the result of a complex interaction between many factors - genetic, environmental and lifestyle. These are outlined below.

\section{Family history}

The increased incidence of Graves' disease among members of the same family signifies that genetic factors may have a significant role in determining the likelihood of developing Graves' disease. ${ }^{3}$ Studies involving twins show a high degree of incidence in both twins, pointing to a major genetics contribution. However, there is a racial variation between major histocompatibility complex (MHC) haplotypes and the greater susceptibility towards Graves' disease. ${ }^{4}$

Some reviews on genetic predisposition for GD have compiled a large number of recent research papers. ${ }^{5}$ It is generally agreed in all of them that multiple genetic factors lead to the risk of GD and that its penetrance is about $30 \%$ in monozygotic twins. There are many variables at play: some of the susceptibility genes are involved in trig- gering immune responses and/or linked to the X chromosome, whereas others seem to be GD-specific (e.g., GD-1, -2 , and -3 ).

Many studies have found an association between cytotoxic $\mathrm{T}$ lymphocyte antigen-4 (CTLA4) and GD. The CTLA4 protein is found in multiple isoforms owing to the genetic polymorphism in the first exon. ${ }^{6}$ This is often linked to another polymorphism of AT dimers at the 3 '-untranslated region of the third exon, which is thought to be associated with increased risk of GD. ${ }^{10}$ This is often connected to another polymorphism of AT dimers at the 3 '-untranslated region of the third exon, which may be associated with increased risk of GD. ${ }^{7}$

Likewise, other associations have been reported with genetic polymorphism in CTLA $4 .^{8}$ This happens by the following mechanism: T lymphocytes express a costimulatory molecule named CD28 on their superficies. During the course of an immune response, the $\mathrm{T}$ cells receive the first signal due to their TCR interactions with the MHCpeptide complexes on the APCs - antigen-presenting cells. The naive lymphocytes need a second signal to be activated. This signal is transmitted through CD28 upon its interaction with specific ligands, B7.1 and B7.2 (CD80 and CD86, respectively), expressed on the surface of APCs. After the activation, T cells regulate CTLA4 expression on their surfaces. The CTLA4, which is structurally linked to the CD28, interacts with CD80 and CD86 with a 100-fold higher affinity. Due to its higher affinity, CTLA4 competes with CD28 for binding to CD80 and CD86. This causes down-modulation of $\mathrm{T}$ cell responses due to negative signalling and/or lack of continued positive signalling. A defective interaction of CTLA4 with its ligands could result in a generalized defect in the down-modulation of the immune responses.

Hence, although the studies on CTLA4 polymorphism are of major interest, as of yet it has not been established how a defect in this gene could specifically amplify the immune response to TSHR and susceptibility to GD. ${ }^{9}$

\section{Sex}

There is a clear sex difference in the prevalence of most autoimmune diseases. Females are generally more frequently affected than males, GD in particular being seven to eight times more common in women than in men. ${ }^{10}$

There are various mechanisms through which gender influences the predisposition to autoimmune diseases: differences in the body's immune response, organ vulnerability, sex hormones, reproductive capacity including pregnancy, parental inheritance, and epigenetics. For this reason, sex is considered an important factor in determining the mechanisms that influence the onset and development of an autoimmune disease.

\section{Age}

Graves' disease typically affects people aged between 30 and 50, but it can develop at any age. ${ }^{11}$ There is a link bet- 
ween age and the symptoms and signs of hyperthyroidism. In a study by Manji et al., 880 patients were examined and grouped by age and sex. Many signs and symptoms showed little change with age until after the fifth decade of life when they began to decrease gradually. Thus, in patients 50 years old and above, the disease becomes more difficult to diagnose as there is not enough information present, and the significance of the existing data may not be appreciated. Hence, identification of the symptoms and signs specific to each age group is the key to improving the rates of early detection and successful treatment of hyperthyroidism. ${ }^{12}$

\section{Other autoimmune disorders}

People suffering of other autoimmune disorders are more likely to develop Graves' disease compared to people without these disorders. Conditions that are linked to Graves' disease will be outlined below. ${ }^{13}$

\section{Rheumatoid arthritis (RA)}

RA is the most widespread arthropathy of inflammatory nature worldwide. It is three times more common in women than in men. Population prevalence in industrialized countries varies between $0.5 \%$ and $1.0 \%{ }^{14}$ and less than $0.5 \%$ in Latin America ${ }^{15}$. The reason is that this region is a colourful mix of cultures and ethnic communities, which determines the differences in the genotypes and phenotypes of RA. ${ }^{16}$

Observations show that the prevalence increases with age and is highest in women over 65 years old. While RA affects most populations around the world, the annual incidence rate varies greatly (between 12 and 1,200 per 100,000 population). This is determined by a variety of factors, including sex, ethnicity, age and the environment (e.g. smoking ${ }^{17}$, infectious diseases $\left.{ }^{18}\right)$, which are all indicative of various hormonal exposures and genetic risks. ${ }^{19}$

In recent decades, many cases of thyroid disorders have been reported in patients with RA, both autoimmune and non-autoimmune in nature. ${ }^{20}$

\section{Pernicious anemia}

Pernicious anemia is a disease caused by vitamin $\mathrm{B}_{12}$ deficiency - a fact established in $1946 .{ }^{21}$ Patients with autoimmune thyroid disease (AITD) have a higher prevalence of pernicious anemia compared to the general population. Clinical signs of $\mathrm{B}_{12}$ deficiency may be subtle and missed, particularly in patients with known autoimmune disease. Ness-Abramof $R$ et al. evaluated the prevalence of vitamin $\mathrm{B}_{12}$ deficiency in patients with AITD and the reliability of measuring fasting gastrin levels in diagnosing said deficiency. Serum $B_{12}$ levels were measured in 115 patients with AITD ( 7 men and 108 women), with a mean age of $47 \pm 15$ years. Serum gastrin and parietal cells (PCA) were measured in patients with low serum $B_{12}$ levels $(\leq 133$ pmol/L). The following results were obtained: $28 \%$ or thirty-two patients with AITD had low $\mathrm{B}_{12}$ levels. Fasting serum gastrin was measured in 26 patients, with elevated levels found in 8 patients. Twenty-seven patients with $\mathrm{B}_{12}$ deficiency were also tested for the presence of PCA, 8 of who tested positive. All patients with high levels of gastrin were diagnosed with atrophic gastritis and 5 patients underwent biopsy gastroscopy. In $31 \%$ of patients who showed high serum gastrin levels and low $\mathrm{B}_{12}$ in the study, pernicious anemia was found. Patients with AITD demonstrated a high incidence of $B_{12}$ deficiency and specifically pernicious anemia. The results of this study show that evaluation of $\mathrm{B}_{12}$ deficiency can be simplified by measuring fasting serum gastrin and, if elevated, referring the patient for gastroscopy. ${ }^{22}$

\section{Lupus}

Many of the studies cited in the specialized literature reveal the high incidence of newly diagnosed AITD cases in patients with systemic lupus erythematosus (SLE), especially in women. A limited number of cases of Graves' disease have also been reported in SLE patients, in line with the higher prevalence of thyroid autoimmunity. On the whole, data from literature strongly suggest that female SLE patients in the high-risk group (with normal but in the upper range levels of thyroid-stimulating hormone, positive antithyroid peroxidase antibodies, a hypoechoic pattern, and a small thyroid gland), should undergo periodic thyroid function check-up and appropriate treatment when needed. Careful thyroid monitoring would be appropriate for these patients. ${ }^{23}$

\section{Addison's disease}

Adrenal insufficiency is of two types, primary and secondary. The primary adrenal insufficiency disease is confined to the adrenal glands, whereas secondary adrenal insufficiency occurs either due to suppression of the hypothalamic-pituitary adrenal axis due to chronic steroid exposure or hypopituitarism due to hypothalamic - pituitary disease. ${ }^{24}$ Graves' thyrotoxicosis and Addison's disease are disorders with a strong autoimmune basis. The association between hyperthyroidism and primary adrenal insufficiency is rarely made. The incidence of Graves' disease in patients with Addison's disease is about $5 \%$ which is nearly 10 times more common than in the general population. ${ }^{25}$

\section{Coeliac disease}

Coeliac disease studies concentrate on its association with hypothyroidism. The impact of coeliac autoimmunity on Graves' disease is less studied. Graves' disease and coeliac disease both have gastrointestinal symptoms such as weight loss and hyperdefecation in common (both are also present in other autoimmune disorders), but there are no guidelines on screening for coeliac disease in cases of Graves' disease. ${ }^{26}$ These associations were seen regardless of temporal sequence and therefore it is suggested that the increased risk of thyroid disease in coeliac patients is an expression of a more general increase in autoimmunity that characterizes many individuals with coeliac disease. The positive association between coeliac disease and thyroid disease may be due to shared genetic or immunological traits. ${ }^{27}$ 


\section{Vitiligo}

This disorder of melanin pigmentation that affects approximately $0.5 \%-2 \%$ of the population ${ }^{28}$ is associated with Graves' disease. Although the pathogenesis of vitiligo is not yet fully understood, the autoimmune hypothesis is the most commonly accepted one. This theory is based on the clinical link between vitiligo and autoimmune disorders, as well as the discovery of circulating autoantibodies and cytoplasmic antigens of melanocytes. Furthermore, there are findings of activated $\mathrm{T}$ cells in the periphery of actively progressing lesions found in patients suffering from vitiligo. There is evidence of a link between some functional disorders of the thyroid gland, autoimmune disorders of the thyroid gland and vitiligo. The frequency of clinical and subclinical thyroid involvement appears to be more frequent in patients with vitiligo than in healthy subjects. ${ }^{29}$

\section{Type $1 A$ diabetes}

This organ-specific autoimmune endocrine disease caused by immune destruction of pancreatic $\beta$ cells $^{30}$ is also associated with Graves' disease. A considerable number of autoantigens, which are also commonly recognized by autoantibodies, are recognized and targeted by CD $8+$ and CD4 + T cells. While these cells normally have a regulatory and protective role, they may also be involved in the destruction of $\beta$ cells. In routine laboratory assays, it has been found that (Pre-) proinsulin ([P] PI), glutamic acid decarboxylase (GAD), tyrosine phosphatase IA-2 and the zinc transporter ZnT8 all have a particularly important role and are recognized by autoantibodies. ${ }^{31}$

When these antibodies are positive, the patient's diabetes is usually considered to be type 1 even if they are not insulin dependent. ${ }^{32}$ Antibodies to islet-related antigens are present before the onset of type 1 diabetes (T1D) ${ }^{33}$, and their predictive value for the development of T1D has been repeatedly investigated in close relatives of T1D patients and the general population. In these patients, titres of GADA tend to be high ${ }^{34}$, which may indicate powerful affinity of the producing autoimmune process to islet antigens.

\section{Environmental and lifestyle factors}

The available data on the environmental factors triggering GD are yet scarce. Environmental and lifestyle factors include nutritive factors, pollutants, drugs and infections. Stress, tobacco and socio-economic milieu also appear to play a substantial role. ${ }^{35}$

\section{Dietary factors}

\section{Iodine}

Iodine intake is unquestionably the most well-established causative factor in the development of TAI. While a daily intake of about $150 \mu \mathrm{g}$ is required for thyroid hormone synthesis, iodine overload exceeding a normal intracellular concentration results in a paradoxical block of the organifi- cation of iodide (the so-called Wolff-Chaikoff effect) and of the iodine intrathyrocyte transport by the sodium-iodide symporter (NIS). ${ }^{36}$

\section{Selenium}

Selenium is of vital importance for human health. When inserted in the form of the genetically encoded amino acid selenocysteine in the proteome, it characterizes the selenoproteins, such as glutathione peroxidases (GPxs) and deiodinases. Selenium thereby potentiates the synthesis of thyroid hormones and optimizes function of the thyroid gland. ${ }^{37}$

\section{Iron}

Iron is important for thyroid hormone synthesis as it catalyses the activity of heme-dependent thyroid peroxidase, while iron deficiency results in impaired thyroid function and blunts the efficacy of iodine intake. ${ }^{38}$

\section{Vitamins}

Certain vitamins, especially $\mathrm{B}_{12}$ and $\mathrm{D}$, have been found to be implicated in the development of GD. Pernicious anemia (PA), a macrocytic anemia caused by vitamin $\mathrm{B}_{12}$ deficiency, is associated with up to $40 \%$ cases of TAI and other autoimmune disorders. ${ }^{39}$

Vitamin D deficiency is a key factor in the increased incidence of autoimmune diseases, including TAI. The vitamin $\mathrm{D}$ receptor (VDR), which is expressed in cells of the immune responses, macrophages, $\mathrm{T}$ cells and $\mathrm{B}$ cells, enhances innate immunity and regulates the adaptive immunity system. ${ }^{40}$

\section{Irradiation}

There is some evidence that internal irradiation, such as radioiodine therapy for toxic goiter or autonomous adenoma in genetically susceptible individuals can cause the Graves' disease. Reports also exist on the association between TAI and external radiation - allegedly dose-response-specific - which warrants further investigation. ${ }^{41}$

\section{Pollutants}

The worldwide rise in industrial activities, often accompanied in developing countries by lax regulation has exacerbated the threat of organic pollution. Increased thyroid volume, presence of thyroid antibodies and elevated levels of polychlorinated biphenyls (PCBs) as well as impaired fasting glucose were detected in 137 females and 94 males, aged 21-35 years, in an area in Slovakia contaminated by organochlorines (OC). ${ }^{42}$

\section{Drugs}

Several drugs have been reported to damage the thyroid functioning as a side effect of their application. ${ }^{43}$ Drugs containing iodine may induce or exacerbate TAI in susceptible persons. Amiodarone, for instance, is an iodine-rich medicinal product, widely used for the treatment of tachyarrhythmias. It often leads to an increase in T4 and rT3 and a 
decrease in serum $\mathrm{T} 3$ concentrations by inhibiting the activity of 5-ideodiodinase, potentially leading to hypothyroidism or hyperthyroidism, the latter proving extremely difficult to grasp. According to members of the European Thyroid Association, there are many uncertainties in the diagnosis and treatment of amiodarone-induced thyrotoxicosis.

\section{Emotional or physical stress}

Stressful life events or illnesses may act as a trigger for the onset of Graves' disease in people who are genetically predisposed. ${ }^{44}$ There is a growing interest in the psychosocial factors for the emergence of GD. Stressful events are of considerable importance in the pathogenesis of certain diseases, their relationship with mental and emotional disorders, and the presence of post-treatment residual symptoms. Examination of past life events may reveal temporal links between them and the onset of endocrine disease symptoms. There is evidence that some pituitary (Cushing's disease, hyperprolactinemia) and thyroid disorders (Graves' disease) are associated with chronic stress. Endocrine disorders are often accompanied by psychological symptoms that can vary greatly, from psychiatric disorders to mild, subclinical forms of mood or anxiety disorders. A population study among a group of patients with autoimmune diseases found that the majority also suffered from at least one of the following conditions described in Diagnostic Criteria for Psychosomatic Research (DCPR): irritability, lack of motivation and constant somatization. Irritable mood in particular was detected in $46 \%$ of patients who had successfully undergone an endocrine disorder treatment.

Long-term endocrine diseases can cause irreversible pathological changes, triggering affective reactions individual to each patient. Patients in whom appropriate endocrine treatment does not alleviate or in fact aggravates symptoms of psychological distress would benefit greatly from appropriate psychiatric therapy, although this seems to be overlooked by most medical professionals. As in other clinical medicine fields, adapting treatment approaches from purely physiological care to a consideration of patients' psychosomatic health and quality of life appears to be essential for enhancing the effectiveness of diagnostics and treatment outcomes in the field of endocrinology. The DCPR has been tested and proven to be a useful tool for psychological assessment in all stages of endocrine disease, from diagnosis to post-treatment phases. ${ }^{45}$

\section{Pregnancy}

Pregnancy or recent birth in genetically susceptible women may lead to an increased risk of autoimmune disorder. ${ }^{46}$ Effective treatment of Graves' disease during pregnancy should be balanced between maternal and fetal health - controlling hyperthyroidism in the mother, while also ensuring minimal negative effects on the fetus from the maternal condition and the medications. The various biochemical, immunological and pharmacological risks posed to the unborn baby by Graves' disease and its treatment have been better understood due to the studies on the subject publis- hed in recent decades. Nevertheless, the choice of an optimal strategy to achieve this complex balance is still a matter of continuous debate in endocrinologists. ${ }^{47}$

\section{Smoking}

Cigarette smoking can affect the immune system thus increasing the risk of Graves' disease. Smokers who have Graves' disease are also at an increased risk of developing Graves' ophthalmopathy. There are numerous studies proving that smoking has an effect on the thyroid gland. Smoking seems to cause changes in some clinical markers: it leads to an increase in thyroid hormones and a decrease in TSH, although these alterations are usually mild. In addition, tobacco smoking may play a role in thyroid autoimmunity. Numerous studies have demonstrated the serious impact of smoking on GD and in particular on orbital ophthalmopathy in various ways: by increasing the risk of developing the disease; by reducing the effectiveness of treatment and, as a result, inducing relapse. In addition to ophthalmopathy, cigarette smoking leads to an increased incidence of multinodular goiter, especially in areas where iodine deficiency is observed. Furthermore, both active and passive smoking during pregnancy might modify maternal and fetal thyroid function. Research has been done on the influence of cigarette smoking on thyroid gland, including hormonal changes, autoimmunity and selected diseases. These findings, however, should be carefully evaluated as some of them are not sufficiently evidence-based. Further studies are required to explain the effects of smoking on thyroid pathophysiology. ${ }^{48}$

\section{Considerations about using the chemometric analysis in the study of the disease}

When analyzing the obtained clinical data, the commonly accepted medical practice is for the value of any particular parameter to be compared to its threshold value or to an interval of permissible values in order to choose a suitable treatment. However, the currently available research suggests that the condition of patients with Graves' disease depends on multiple factors, which makes it important to substitute the current one-dimensional medical practice with a more comprehensive approach. ${ }^{49}$

All clinical factors and their interrelationships must be analyzed concurrently rather than as separate entities in order to make a correct diagnostic decision. It is now possible to do so by the application of methods for classification modeling and the interpretation of multivariate statistics known as chemometric analysis.

Chemometric analysis allows for the detection of specific relationships between the medical parameter measurements obtained from the patients in an observation group, and the identification of patterns of similarity between these patients. It is not commonly used in clinical trials but there are already indications for its specific role as a medical statistics tool. 
Chemometrics is not commonly used in clinical studies. It allows for the detection of specific relationships between the medical parameter measurements obtained from the patients in an observation group, and the identification of patterns of similarity between these patients. The implementation of this method in future trials would provide more reliable information which may help in creating more successful, individualised treatment strategies for established groups (patterns) of patients. ${ }^{50}$

\section{CONCLUSIONS}

The evidence for pathophysiological interactions between genetic and environmental factors and their understanding discussed in this paper may allow for the development of preventive measures or better tailoring of therapies.

The chemometric analysis can be a useful method in finding the relationships between the medical parameter measurements for the development of preventive actions.

\section{Competing interests}

All authors declare there are no conflicts of interests in connection with this paper.

\section{Authors contribution}

All authors have contributed to the design and implementation of the review article and to the writing of the manuscript with the provided critical feedback. Prof. Zdravko Kamenov provided the study topic, was in charge of directing and supervising the findings of this study. Assoc. prof. Pavlina Andreeva-Gateva, Pavlina Koseva and Mariana Nikolova wrote the manuscript with input from prof. Zdravko Kamenov. Assoc. prof. Pavlina Andreeva-Gateva was indicated as a corresponding author.

\section{REFERENCES}

1. Heller O, Somerville C, Suggs LS, et al. The process of prioritization of non-communicable diseases in the global health policy arena. Health Policy Plan 2019; 34(5):370-83.

2. Zhang R, Tan J, Wang R, et al. Analysis of risk factors of rapid thyroidal radioiodine-131 turnover in Graves' disease patients. Sci Rep 2017; 7:8301.

3. Rüst CA, Knechtle B, Rosemann T. Graves' disease in monozygotic twins - a case report. BMC Endocr Disord 2013; 13:17.

4. Mora N, Vu KN, Hoang TD, et al. R-CHOP-associated Graves' hyperthyroidism. Case Rep Oncol 2019; 12:581-8.

5. Vejrazkova D, Vcelak J, Vaclavicova, et al. Genetic predictors of the development and recurrence of Graves' disease. Physiol Res 2018; 67(Suppl. 3):S431-9.

6. Ahmed NS. The codon 17 polymorphism of the CTLA4 gene in type
1 diabetes mellitus in the Baghdad population. J Med Genet Genomics 2014; 6(1):1-5.

7. Du P, Ma X, Wang C. Associations of CTLA4 gene polymorphisms with Graves' ophthalmopathy: a meta-analysis. Int J Genomics 2014; 537969.

8. Pastuszak-Lewandoska D, Sewerynek E, Domańska D, et al. CTLA-4 gene polymorphisms and their influence on predisposition to autoimmune thyroid diseases (Graves' disease and Hashimoto's thyroiditis). Arch Med Sci 2012; 8(3):415-21.

9. Eliana F, Suwondo P, Asmarinah A, et al. The role of cytotoxic Tlymphocyte-associated protein 4 (CTLA-4) gene, thyroid stimulating hormone receptor (TSHR) gene and regulatory T-cells as risk factors for relapse in patients with Graves' disease. Acta Medica Indonesiana 2017; 49(3):195-204.

10. Ngo ST, Steyn FJ, McCombe PA. Gender differences in autoimmune disease. Front Neuroendocrinol 2014; 35(3):347-69.

11. Smith TJ, Hededüs L. Graves' disease. N Engl J Med 2016; 375(16):1552-65.

12. Balhara YS, Deb KS. Impact of tobacco on thyroid function. Thyroid Res Pract 2014; 11:6-16.

13. Atanasova I, Kamenov Z, Zaharieva E. [Autoimmunity and endocrine disorders.] Sofia: Erato Art; 2012: 136 [In Bulgarian].

14. Wu J, Li J, Li S, et al. Association of HLA-DQB1 polymorphisms with rheumatoid arthritis: a meta-analysis. Postgraduate Medical Journal 2017; 93(1104):618-25.

15. Cardiel MH, Díaz-Borjón A, Vázquez del Mercado Espinosa M, et al. [Update of the Mexican guide for pharmacological treatment of rheumatoid arthritis of the Mexican College of Rheumatology]. Reumatol Clin 2014; 10:227-40. [In Spanish].

16. Pedersen JK, Svendsen AJ, Hørslev-Petersen K. Prevalence of rheumatoid arthritis in the southern part of Denmark. Open Rheumatol J 2011; 5:91-7.

17. Johnson C, Giles JT, Bathon J, et al. Smoking and subclinical ILD in RA versus the multi-ethnic study of atherosclerosis. PLoS ONE, 2016; 11(4):e0153024.

18. Meron MK, Amital H, Shepshelovich D, et al. Infectious aspects and the etiopathogenesis of rheumatoid arthritis. Clin Rev Allergy Immunol 2010; 38(2-3):287-91.

19. Quintero OL, Amador-Patarroyo M, Montoya-Ortiz G, et al. Autoimmune disease and gender: plausible mechanisms for the female predominance of autoimmunity. J Autoimmun 2012; 38(2-3):109-19.

20. Cárdenas Roldán J, Amaya-Amaya J, Castellanos-de la Hoz J, et al. Autoimmune thyroid disease in rheumatoid arthritis: a global perspective. Arthritis 2012; 2012:864907.

21. Hegazi MO, Ahmed S. Atypical clinical manifestations of Graves' disease: an analysis in depth. J Thyroid Res 2012; 2012:768019.

22. Collins AB, Pawlak R. Prevalence of vitamin B-12 deficiency among patients with thyroid dysfunction. Asia Pac J Clin Nutr 2016; 25(2):221-6.

23. Ferrari SM, Elia G, Virili C, et al. Systemic lupus erythematosus and thyroid autoimmunity. Front Endocrinol (Lausanne) 2017; 8:138.

24. Charmandari E, Nicolaides NC, Chrousos GP. Adrenal insufficiency. Lancet 2014; 383(9935):2152-67.

25. Dukhabandhu N, Jebasingh KF, Thomas N. Delayed diagnosis of Graves' thyrotoxicoisis presenting as recurrent adrenal crisis in primary adrenal insufficiency. J Clin Diagn Res 2016; 10(4):OD20-2.

26. Freeman HJ. Endocrine manifestations in celiac disease. World J Gastroenterol 2016; 22(38):8472-9. 
27. Sun X, Lu L, Yang R, et al. Increased incidence of thyroid disease in patients with celiac disease: a systematic review and meta-analysis. PLoS ONE 2016; 11(12):e0168708.

28. Singh M, Mansuri MS, Parasrampuria MA, et al. Interleukin 1- $\alpha$ : A modulator of melanocyte homeostasis in vitiligo. Biochem Anal Biochem 2016; 5:273.

29. Vrijman C, Kroon MW, Limpens J, et al. The prevalence of thyroid disease in patients with vitiligo: a systematic review. Br J Dermatol 2012; 167(6):1224-35.

30. Michels AW, Eisenbarth GS. Immune intervention in type 1 diabetes. Semin Immunol 2011; 23(3):214-219.

31. Shimura K, Miura J, Kawamoto M, et al. Genetic differences between type 1 diabetes with and without other autoimmune diseases. Diabetes Metab Res Rev 2018; 34(7):e3023.

32. Roizen JD, Bradfield JP, Hakonarson H. Progress in understanding type 1 diabetes through its genetic overlap with other autoimmune diseases. Current Diabetes Reports 2015; 15(11):102.

33. Bingley PJ. Clinical applications of diabetes antibody testing. Clin Endocrinol Metab 2010; 95(1):25-33.

34. Katahira M, Ogata $H$, Ito $T$, et al. Association of autoimmune thyroid disease with anti-GAD antibody ELISA test positivity and risk for insulin deficiency in slowly progressive type 1 diabetes. J Diabetes Res 2018:1847430.

35. Duntas L. Environmental factors and autoimmune thyroiditis. Nat Clin Pract Endocrinol Metab 2010; 4:454-60.

36. Burgi H. Iodine excess. Best Pract Res Clin Endocrinol Metab 2010; 24:107-15.

37. Pakdel F, Ghazavi R, Heidary R, et al. Effect of selenium on thyroid disorders: scientometric analysis. Iran J Public Health 2019; 48(3):410-20.

38. Manisha A, Roshan KM, Sudeep K, et al. Study of trace elements in patients of hypothyroidism with special reference to zinc and copper. Biomed J Sci \& Tech Res 2018; 6(2):5190-5194.

39. Lenti MV, Lahner E, Bergamaschi G, et al. Cell blood count altera- tions and patterns of anaemia in autoimmune atrophic gastritis at diagnosis: a multicentre study. J Clin Med 2019; 8(11):1992.

40. Hewison M. Vitamin D and immune function: Autocrine, paracrine or endocrine? Scand J Clin Lab Invest Suppl 2012; 243:92-102.

41. Gallo D, Mortara L, Gariboldi MB, et al. Immunomodulatory effect of vitamin $\mathrm{D}$ and its potential role in the prevention and treatment of thyroid autoimmunity: a narrative review. J Endocrinol Invest 2020; 43:413-29.

42. Bílek R, Horáková L, Goš R, et al. Thyroid disease in the Czech Republic: the EUthyroid project and the evaluation of the General Health Insurance Company epidemiological data for the period of 2012-2015. Vnitř Lék 2017; 63(9):548-54.

43. Barbesino G. Drugs affecting thyroid function. Thyroid 2010; 20: 763-70.

44. Fukao A, Takamatsu J, Arishima T, et al. Graves' disease and mental disorders. J Clin Transl Endocrinol 2019; 19:100207.

45. Ranabir S, Reetu K. Stress and hormones. Indian J Endocr Metab 2011; 15:18-22.

46. Uenaka M, Tanimura K, Tairaku S, et al. Risk factors for neonatal thyroid dysfunction in pregnancies complicated by Graves' disease. Eur J Obstet Gynecol Reprod Biol 2014; 177:89-93.

47. Laurberg P, Andersen SL. Endocrinology in pregnancy: Pregnancy and the incidence, diagnosing and therapy of Graves' disease. Eur J Endocrinol 2016; 175(5):219-30.

48. Sawicka-Gutaj N, Gutaj P, Sowiński J, et al. Influence of cigarette smoking on thyroid gland - an update. Endokrynol Pol 2014; 65(1):54-62.

49. Tomova R, Tzaneva P, Nikolov M, et al. Interpretation of data in patients with enteral and parenteral nutrition. Cent Eur J Med 2012; 7(6):720-8.

50. Andreeva-Gateva P, Konsulova P, Orbetzova M, et al. Multivariate statistical interpretation of obese patients at moderate or higher Findrisc score based on their atherogenic index. Postgrad Med 2016; 128 (8):790-6. 


\title{
Базедова болезнь: патофизиологические аспекты и соображения относительно использования хемометрического анализа при изучении болезни
}

\author{
Павлина М. Косева ${ }^{1}$, Здравко А. Каменов ${ }^{2}$, Мариана М. Николова ${ }^{3}$, \\ Павлина А. Андреева-Гатева ${ }^{4}$ \\ ${ }^{1}$ Кафедра фармацевтической химии, Фармацевтический факультет, Медицинский университет - Варна, Варна, Болгария \\ ${ }^{2}$ Клиника эндокринологии, Медицинский университет - София, УМБАЛ „Александровска“, София, Болгария \\ ${ }^{3}$ Кафедра психического здоровья, сочиальной работы и интегративной медицины, Мидлсекский университет, Лондон, Объединённое \\ Королевство \\ ${ }^{4}$ Кафедра фармакологии и токсикологии, Медицинский университет - София, София, Болгария
}

Адрес для корреспонденции: Павлина А. Андреева-Гатева, Кафедра фармакологии и токсикологии, Медицинский университет - София, ул. „Здраве“ №2, 1431 София, Болгария; E-mail: pandreeva_gateva@outlook.com; Тел.: +359 889428105

Дата получения: 3 августа 2020 Дата приемки: 4 сентября $2020 \bullet$ Дата публикации: 31 августа 2021

Образец цитирования: Koseva PM, Kamenov ZA, Nikolova MM, Andreeva-Gateva PA. Graves' disease: pathophysiological aspects and considerations about using the chemometric analysis in the study of the disease. Folia Med (Plovdiv) 2021;63(4):467-74. doi: 10.3897/folmed.63.e57193.

\section{Резюме}

Базедова болезнь - это нарушение иммунной системы, которое приводит к гиперпродукции гормонов щитовидной железы (гипертиреоз). Заболевания щитовидной железы представляют собой социальные проблемы, вызывающие большой общественный интерес из-за их высокой частоты. Эта проблема может повлиять на самочувствие и качество жизни пациентов. Факторы, предрасполагающие к этому заболеванию, еще полностью не изучены и, вероятно, сложным образом взаимосвязаны. Хемометрический анализ позволяет установить конкретные отношения между измерением медицинских параметров, взятых у пациентов в наблюдаемой группе, и идентификацией моделей сходства между этими пациентами. Он не часто используется в клинических испытаниях, но может предоставить надёжную информацию, которая поможет выстроить успешные индивидуализированные стратегии для установленных групп (моделей) пациентов.

Целью этого обзора было обобщение последних данных о факторах риска базедовой болезни и соображений относительно использования хемометрического анализа при изучении этого заболевания.

\section{Ключевые слова}

аутоиммунитет, зоб, обзор, факторы риска 